\title{
MAREK FIAŁKOWSKI \\ Znaki czasu. Próba definicji w świetle polskich publikacji teologicznych po Soborze Watykańskim II
}

Teologia znaków czasu jest nie tylko ważnym elementem pastoralnej i społecznej strategii Kościoła, ale także jedną z podstawowych kategorii teologicznych związanych z odczytaniem wzajemnych relacji Kościoła ze światem. Jest ona również narzędziem dialogu i otwarcia Kościoła na świat współczesny ${ }^{1}$. Kluczową kwestią wspomnianej teologii jest określenie czym są znaki czasu, które zjawiska można za nie uznać i jak należy je interpretować. Zasadne zatem wydaje się pytanie, jaka definicja znaków czasu wyłania się z polskich publikacji teologicznych po Soborze Watykańskim II?

Poszukując odpowiedzi na tak postawione pytanie najpierw ukazane zostaną trudności na jakie napotyka się w procesie definiowania terminu znaki czasu. Następnie omówione zostaną istotne cechy znaków czasu i wreszcie zostanie podjęta próba zdefiniowania znaków czasu w świetle polskich publikacji teologicznych po Soborze Watykańskim II.

\section{Trudności w definiowaniu znaków czasu}

Jak zauważa Józef Majka, od czasu, kiedy Jan XXIII wykorzystał w swoim nauczaniu biblijny termin znaki czasu, nadając mu nowe znaczenie, termin ten

Marek F I A Ł K O W S K I OFMConv, dr hab., adiunkt w Katedrze Teologii Pastoralnej Szczegółowej Instytutu Teologii Pastoralnej i Katechetyki KUL; Lublin, e-mail: jdszkot@kul.lublin.pl; www.lublin.franciszkanie.pl

\footnotetext{
${ }^{1}$ Por. J. G o c k o: Kościót obecny w świecie - postany do świata. Teologiczno-spoteczne aspekty postannictwa Kościoła w świecie po Soborze Watykańskim II. Lublin 2003 s. 225.
} 
zrobił niemałą karierę i przebył dość odległą drogę semantyczną ${ }^{2}$. Jednak do dziś nie doczekał się ścisłego i dokładnego sprecyzowania. Ani w nauczaniu ostatnich papieży, ani w dokumentach soborowych nie znajdziemy ścisłej definicji znaków czasu. Posoborowa teologia także nie wypracowała definicji interesującego nas pojęcia, które zadowoliłoby wszystkich. Wydaje się, że trudności z wypracowaniem właściwej definicji znaków czasu wynikają z konieczności uwzględnienia w niej dwóch aspektów: nadprzyrodzonego i doczesnego, które wzajemnie się nakładają i przenikają. Konieczność utrzymania właściwej równowagi pomiędzy nimi pozwala uniknąć niebezpieczeństwa redukcjonistycznego ujęcia terminu znaki czasu w teologii. Zarówno aspekt nadprzyrodzony jak i doczesny nie może być przeakcentowany. W przypadku dominacji aspektu doczesnego znaki czasu sprowadzałyby się do zwykłych wydarzeń historycznych z pominięciem obecnych w nich znaków innej rzeczywistości. Natomiast kiedy przeakcentowany zostaje wymiar nadprzyrodzony może to prowadzić do traktowania znaków czasu $\mathrm{w}$ kategoriach wydarzeń cudownych $\mathrm{z}$ pominięciem ich naturalnego charakteru ${ }^{3}$.

$\mathrm{Z}$ podobnymi trudnościami mamy do czynienia w procesie interpretacji znaków czasu. Paweł VI zwraca uwagę na najważniejsze niebezpieczeństwa, które mogą wystąpić podczas ich interpretacji ${ }^{4}$. Pierwsze z nich to pseudoprofetyzm, który jest mistyfikacją, zrodzoną z pochopnego uciekania się do nadprzyrodzonych czynników tam, gdzie ich w rzeczywistości nie ma. Przypadkowym zbieżnościom, często nic nie znaczącym, nadaje się cudowne wyjaśnienia. Ponieważ obserwowane fakty dają możliwość dwuznacznej oceny, niezbędna jest pomoc Urzędu Nauczycielskiego Kościoła, którego opina jest rozstrzygająca.

Drugim niebezpieczeństwem jest socjologizm, który zakłada, że najbardziej miarodajnym źródłem i kryterium ocen wszelkich wydarzeń są ich społeczne skutki. Redukuje się wówczas interpretację znaków czasu wyłącznie do wymiaru zewnętrznego, zjawiskowego i społecznego. Pomija się zaś ich wymiar moralny i religijny. Socjologia jest niezbędna na etapie wstępnym interpretacji znaków czasu, ale na tym etapie nie można poprzestać. Konieczne jest także otwarcie na wymiar nadprzyrodzony znaków czasu.

Trzecie niebezpieczeństwo to historycyzm, który przypisuje dominującą rolę aspektowi historycznemu znaków czasu. Nie należy oczywiście lekceważyć czasu i historii, gdyż poprzez Wcielenie obie te rzeczywistości wchodzą w ekonomię

\footnotetext{
${ }^{2}$ Por. J. M a j k a: Sens ,znaków czasu”. „Chrześcijanin w Świecie”. R. 5: 1973 nr 1 s. 3.

${ }^{3}$ Por. P. N i t e c k i: Rozpoznać znaki nowych czasów. Nad przestaniem Jana Pawta II po Wielkim Jubileuszu chrześcijaństwa. Warszawa 2002 s. 137-138; P. G ó r a l c z y k: Chrześcijanin otwarty na znaki czasu. „Communio” Międzynarodowy Przegląd Teologiczny. R. 19: 1999 nr 6 s. 4.

${ }^{4}$ Por. P a w e ł V I: Przemówienie z 16.04.1969 r. o odczytywaniu znaków czasu. „Miesięcznik Diecezji Gdańskiej”. R. 14:1970 nr 12 s. 381.
} 
zbawczą, jako środki i narzędzia Bożego działania w uświęcaniu ludzi. Jednak niezmienny element Objawienia nie może podlegać zmienności czasów, w których bywa umiejscowiony i w których ujawnia się poprzez znaki, które go nie zmieniają, ale ukazują pielgrzymującemu Ludowi Bożemu. Ważne jest także, aby konkretnych wydarzeń historycznych, zrozumiałych i aktualnych dla danej epoki nie wyabstrahowywać do rzędu zjawiska ogólnoludzkiego lub ponadczasowego oraz aby tych historycznych wydarzeń nie interpretować według założeń jednej tylko ideologii ${ }^{5}$.

Błąd każdego z wymienionych stanowisk polega na przewartościowaniu bądź to aspektu doczesnego, który interpretowany w świetle nadprzyrodzonym nabiera dopiero charakteru znaku czasu, bądź elementu nadprzyrodzonego w osądzie rzeczywistości. Pomiędzy tymi skrajnościami mieści się cała refleksja teologii znaków czasu, która musi zabiegać o precyzyjne rozróżnianie zjawisk doczesnych, ziemskich i historycznych, bez czego trudno mówić o zrozumieniu ich głębszego, symbolicznego znaczenia. Naturalna wrażliwość na obserwowane wydarzenia oraz widzenie $\mathrm{w}$ nich dzięki wierze elementu dialogu między Bogiem i człowiekiem, nie mogą być rozpatrywane w oderwaniu od siebie. Jest to bowiem jeden proces odczytywania doczesnych wydarzeń jako znaku treści nadprzyrodzonych $^{6}$.

Biorąc to wszystko pod uwagę musimy zadowolić się opisowym określeniem pojęcia znaki czasu. Ponadto trzeba być przygotowanym na różnorodne próby definiowania interesującego nas terminu? ${ }^{7}$.

\section{Cechy znaków czasu}

Znaki czasu charakteryzują się powszechnością i częstotliwością. Zdaniem Apoloniusza Żynela znaki czasu można traktować jako zjawiska powszechne w podwójnym znaczeniu. Najpierw w wymiarze rzeczowym, gdyż zjawiska te rozciągają się na wiele dziedzin życia i obejmują różne formy ludzkiej aktywności. Nie mogą zatem być brane pod uwagę fakty odosobnione i wyizolowane, ponieważ nie mają wymowy głosów epoki. W drugim znaczeniu chodzi o powszechność psychologiczną czyli o powszechne uświadomienie sobie pewnych potrzeb i dążeń charakterystycznych w danej epoce ${ }^{8}$.

Stanisław Bielecki wylicza jeszcze sześć cech znaków czasu: zmienność, relatywność, powiązanie z życiem, wieloznaczność, wzajemne nakładanie się znaków czasu oraz fakt, że znaki czasu nie są jedynym sposobem przymawiana Bo-

\footnotetext{
${ }^{5}$ Por. A. Ż y n e l: Znaki czasu. „Znak”. R. 21: 1969 nr 186 s. 1591-1593

${ }^{6}$ Por. G o c k o: Kościót obecny w świecie - postany do świata, dz. cyt., s. 222-223.

${ }^{7}$ Por. Nit e c k i, dz. cyt., s. 138.

${ }^{8}$ Por. A. Ż y n e l, dz. cyt., s. $1586-1587$.
} 
ga. Zmienność przypomina o powiązaniu znaków czasu ze zmieniającym się czasem i historią. Wraz z ich zmianą także znaki czasu podlegają przemianom, jedne tracą na znaczeniu lub zmieniają aspekt, albo też pojawiają się nowe.

Z kolei relatywność wskazuje na fakt, że te same znaki czasu nie muszą pojawiać się we wszystkich miejscach i kulturach. Są zatem względne i co do czasu jaki i do przestrzeni, co każe pamiętać, że znaków czasu nie wolno absolutyzować czy przypisywać im jednakowe znaczenie w każdym czasie i przestrzeni.

Cechą znaków czasu jest także ich powiązanie z życiem. Pozostają zatem aktualne i popularne w konkretnym czasie i przestrzeni, odnosząc się do spraw, którymi żyje i których doświadcza konkretny człowiek. Pozwala to lepiej dostrzegać Boga obecnego w historii oraz ułatwia przezwyciężanie dualizmu zasad głoszonych przez chrześcijańską wiarę, a praktyki codziennego życia wierzących.

Wieloznaczność, jako kolejna cecha znaków czasu, przypomina, że zjawiska te mają wymiar historyczny, socjologiczny oraz teologiczny. Wymiary te trzeba uwzględniać, unikając pomijania jednych kosztem drugich lub ich utożsamiania. Biorąc pod uwagę obecność zła w świece, jak i wielowymiarowość znaków czasu trzeba zwrócić szczególną uwagę na proces właściwej ich interpretacji. Nie jest to łatwe, jeśli uświadomimy sobie kolejną ich cechę, to znaczy wzajemne nakładanie się znaków czasu. Przypomina ona, że znaki czasu wyrażają różnorodność ludzkich aspiracji, wartości i natchnień Bożych, które wzajemnie się nakładają i splatają. Utrudnia to także klasyfikacje znaków czasu oraz sporządzanie pełnego i trwałego ich katalogu'.

I wreszcie cecha przypominająca, że znaki czasu nie są jedynym sposobem przemawiania Pana Boga do współczesnych ludzi. Znaków czasu nie można bowiem rozumieć w oderwaniu od Objawienia. Jeśli istotnie mają być one rozumiane jako źródło poznania woli Bożej muszą być zatem interpretowane w kontekście Objawienia ${ }^{10}$.

\section{Próba definicji znaków czasu}

W sensie socjologicznym znaki czasu są to zjawiska, które z racji swego upowszechnienia i częstotliwości charakteryzują epokę i za pośrednictwem których wyrażają się potrzeby i aspiracje dzisiejszych ludzi ${ }^{11}$. Socjologiczne spoj-

\footnotetext{
${ }^{9}$ Por. S. B i e le c k i: Teologia znaków czasu. Kielce 2006 s. 187-188.

${ }^{10}$ Por. N i t e c k i, dz. cyt., s. 152.

${ }^{11}$ Definicja wypracowana podczas Soboru Watykańskiego przez K. D e 1 a h a y e i F. H o u t a r t a [cyt. za M. D. C h e n u: Znaki czasu refleksja teologa. „Chrześcijanin w Świecie”. R. 1: 1969 nr 1 s. 50]; zob. W. Le s z c z y ń s k i: Posoborowa teologia znaków czasu. „Życie i Myśl”. R. 22: 1972 nr 10 s. 44.
} 
rzenie na rzeczywistość pozwala dostrzec w znakach czasu pewne zjawiska czy tendencje pojawiające się czy to z jaką́s określoną częstotliwością, czy utrzymujące się przez dłuższy czas i uzyskujące jakiś szczególny zasięg ${ }^{12}$.

Znaki czasu są rzeczywistością społeczno-historyczną i plasują się w dziedzinie kultury ${ }^{13}$. Dotyczą zatem życia ludzi i są zjawiskami o charakterze humanistycznym, nie zaś przyrodniczym. Można uznać, że znaki czasu, będące zjawiskami, wydarzeniami i przemianami wytworzonymi przez człowieka, nie są przejawami jakiejś bezpośredniej interwencji Bożej. Jeśli jest w nich obecne działanie Ducha Świętego, to w taki sposób, że działa on poprzez swoje natchnienia i oświecenie wewnętrzne w stosunku do człowieka, a nie przez jakąś interwencję zewnętrzną. Odnosząc się do spraw historycznych, społeczno-gospodarczych i kulturowych prowokują, a nawet zmuszają do zajęcia stanowiska. Są zatem zjawiskami sięgającymi głęboko w sprawy ludzkiego życia, na różnych jego poziomach i płaszczyznach. W takim ujęciu znaki czasu nie zawsze są zjawiskami pozytywnymi, ale w każdym wypadku stawiają człowiekowi trudne i głębokie pytania dotyczące sensu życia ${ }^{14}$.

Przy definiowaniu terminu znaki czasu trzeba uwzględniać dwa elementy: czasowo-kulturowy i moralno-religijny. Pierwszy wyznacza szeroki zakres najważniejszych dla współczesnego świata zjawisk, które można uznać za znaki czasu. Wydaje się, że należy szukać znaków czasu w nowych sytuacjach i procesach dokonujących się w strukturach społeczeństwa, w życiu politycznym, w systemie wartości, w pozycjach jednostki wobec społeczeństwa, których w poprzednich okresach nie było i które ostro wyróżniają współczesność od czasów przeszłych, a spośród nich te zjawiska, które mają wymiar moralny i odnoszą się w jakiś sposób do sytuacji Kościoła ${ }^{15}$. Znaki czasu byłyby zatem pewnymi zjawiskami, tendencjami rozwojowymi czy stanami świadomości, charakterystycznymi dla rzeczywistości społecznej danego okresu, znamionującymi swego rodzaju wychylenie tej rzeczywistości w przyszłość i stanowiącymi zapowiedź przyszłego jej oblicza. Można uznać je za zapowiedź i początek narastających procesów przemian, które są już dziś wyraźnie dostrzegalne i do których trzeba się ustosunkować ${ }^{16}$.

${ }^{12}$ Por. S. T. Zarzy cki: Znaki czasu. W: Leksykon duchowości katolickiej. Red. M. C h m i e le w s ki. Lublin-Kraków 2002 s. 960.

${ }^{13}$ Por. A. Z u b e r b i e r: Materiaty do teorii teologii praktycznej. Skrypt dla studentów. Warszawa 1974 s. 71; B. P r z y b y ls k i: Znaki czasu. „Ateneum Kapłańskie”. T. 62: 1970 nr 366 s. 133-141.

${ }^{14}$ Por. M ajk a: Sens „znaków czasu”, dz. cyt., s. 10. Nie wszyscy podzielają pogląd, że „znaki czasu” mogą być zjawiskami negatywnymi.

${ }^{15}$ Por. S. K u r o w s k i: Sesja ODISS na temat „znaków czasu”. „Chrześcijanin w Świecie”. R. 1: $1969 \mathrm{nr} 1 \mathrm{s.} 71$.

${ }^{16}$ Por. J. M a j k a: Jaka Polska? Węzłowe problemy katolickiej nauki spotecznej. Wrocław 1991 s. 9. 
Jak zauważa Leszek Kuc, dokumenty Soboru Watykańskiego II używają zamiennie na określenie znaki czasu wyrażania znaki obecności Bożej (KDK 11). Te drugi termin można potraktować jako interpretację wyrażenia znaki czasu. W ten sposób znaki czasu przypisane zostałyby do porządku zbawienia i traktowane jako znaki nadziei. Ukazuje to niezbędność teologicznego określenia interesującego nas terminu ${ }^{17}$.

W świetle nauczania Soboru Watykańskiego II znaki czasu to zjawiska, wydarzenia i procesy, w których przejawia się działanie Ducha Świętego, ingerujące w dzieje ludzkości przez pobudzanie i oświecanie ludzkich serc (zob. KDK 11). Jan Paweł II podkreślał, że znaki czasu Sobór Watykański II określa jako [...] znaczace przejawy obecności i działania Ducha Bożego $w$ dziejach ${ }^{18}$. Zjawiska te wymagają konfrontacji $\mathrm{z}$ nauką ewangeliczną i zaangażowaniem chrześcijan w kierunku poszerzania tych zjawisk lub ich przemiany. Kościół nie może być obojętny wobec tych wydarzeń, zjawisk i procesów gdyż albo z nich samych, albo z Ewangelii z nimi skonfrontowanej wynika wezwanie do działania ${ }^{19}$. Znaki czasu można zatem uznać za stale aktualizowane ze strony Boga wezwanie kierowane do człowieka, poszczególnych ludzi i całych społeczeństw w konkretnym momencie historii i w określonych okolicznościach ${ }^{20}$.

Według Pawła VI znaki czasu stanowią wyodrębnione, zindywidualizowane w czasie, to znaczy w biegu wydarzeń, znaki, które mogą nam dać wiadomość o wiecznej Opatrzności lub mogą być objawem jakiegoś stosunku do Królestwa Bożego w jego tajemniczej działalności; czy też objawem możliwości, dyspozycji, wymaganiami stawianymi działalności apostolskiej. Znaki czasu według tego ujęcia byłyby teologiczną interpretacja współczesnej historii, wykrywaniem zamysłu Bożego i ekonomii transcendentnej w toku wydarzeń, które do Jezusa Chrystusa prowadzą i od Chrystusa dochodzą ${ }^{21}$.

Znaki czasu tworzą na swój sposób miejsce teologiczne, w którym należy szukać wezwań i podszeptów Ducha Świętego. Przejawia się w nich zatem wola Boża w stosunku do ludzkości. Znaki czasu są obok Objawienia jeszcze jednym źródłem poznania woli Bożej w stosunku do człowieka oraz Jego obecności wśród ludzi. Oba te źródła muszą być pojmowane i interpretowane we wzajem-

17 Tamże, s. 72.

18 Jan Paweł II: Duch a ,znaki czasu”. Przemówienie na audiencji generalnej 23.09.1998 r. „L'Osservatore Romano”. Wydanie polskie. R. 20: 1999 nr 1 s. 46.

${ }^{19}$ Por. M a j k a: Sens ,znaków czasu”, dz. cyt., s. 9.

${ }^{20}$ Por. N i t e c k i, dz. cyt., s. 135; A. Z u b e r b i e r: Znaki czasu. W: Stownik teologiczny. Red. A. Z u berbi er. Katowice $1998^{2}$ s. 691.

${ }^{21}$ Por. P a w e ł V I: Przemówienie z 16.04.1969 r. o odczytywaniu znaków czasu, dz. cyt., s. 380; G. Potarzyńs ki: „Znaki czasu” w Kościele soborowym. „Życie Katolickie”. R. 4: $1985 \mathrm{nr} 6$ s. 95. 
nym odniesieniu ${ }^{22}$. Stanisław C. Napiórkowski zalicza znaki czasu do nie zobiektywizowanych źródet teologii ${ }^{23}$. Znaki czasu, będąc wezwaniami Bożymi i apelem skierowanym do człowieka, prowadzą go do uświadomienia właściwego kierunku rozwoju świata oraz skłaniają go, aby swoje życie dostroił do tego kierunku, gdyż na tej drodze może włączyć się w Boże plany. Stefan Moysa traktuje znaki czasu jako miejsce przygotowania do głoszenia Ewangelii. Nie są bezpośrednio objawieniem ani słowem Bożym, pozostają najczęściej ukryte i trudne do rozpoznania wśród mnóstwa innych faktów i wydarzeń. Wskazują jednak na kierunek, w którym należy postępować, aby rozwój świata był zgodny z myślą Bożą, oraz ukazują na jakim gruncie Ewangelia będzie przyjmować się szczególnie pomyślnie ${ }^{24}$.

Trzeba jeszcze zwrócić uwagę na polskie tłumaczenie wyrażenia znaki czasu. Termin ten w Biblii występuje w liczbie mnogiej (gr. ta semeia tôn kairôn; łac. signa autem temporum) jednak większość polskich przekładów Pisma Świętego używa wyrażenia znaki czasu, zamiast znaki czasów. Podobnie jest w polskiej literaturze teologicznej. Zdaniem Bronisława Mierzwińskiego poprawna forma w języku polskim to znaki czasu, a nie znaki czasów. To ostatnie wyrażenie jest, zdaniem wspomnianego autora, niewolniczym tłumaczeniem łacińskiego terminu signa temporum ${ }^{25}$. Z drugiej strony trzeba zauważyć, że w oficjalnym tłumaczeniu dokumentów soborowych na język polski znalazła się druga forma czyli znaki czasów ${ }^{26}$.

Marian Filipiak uważa, że drobna zmiana w wyrażeniu znaki czasu, to znaczy użycie słowa „czas” w liczbie pojedynczej, wskazuje, że język teologiczny rozszerzył sens biblijnej formuły mające znaczenie mesjańskie i eschatologiczne (Mt 16, 1-4), na każdy czas. Problem znaków czasu w publikacjach teologicznych jest łączony z problemem przemian współczesnego świata, zaś za znaki czasu uważa się zjawiska, wydarzenia i procesy mieszczące się w historycznym $\mathrm{i}$ społecznym rozwoju społeczeństw ludzkich. Po nich poznaje się problemy i dążenia współczesnych ludzi, ich rozmiar i ukierunkowanie. Należy je bacznie

\footnotetext{
${ }^{22}$ Por. Ch e n u, dz. cyt., s. 50; J. M a j k a: Metodologia nauk teologicznych. Wrocław 1981 s. 244.

${ }^{23}$ S. C. N a p i ó r k o w s k i: Jak uprawiać teologię. Wrocław $1994^{2}$ s. 39-41; zob. N i t e c k i, dz. cyt., s. 140 .

${ }^{24}$ Por. S. M o y s a: Rozeznawanie znaków czasu w Duchu Świętym. W: Napetnieni Duchem Świętym. Poznań 1982 s. 134-135.

${ }^{25}$ Por. B. M i e r z w i ń s k i: Specyfika polskich znaków czasu. W: Duszpasterstwo a wyzwania XXI wieku. Materiały z Sympozjum Pastoralistów Polskich. 22-24 kwietnia 2001 r. Kielce. Kielce 2001 s. 65; zob. Ż y n e 1, dz. cyt., s. 1581.

${ }^{26}$ Jest tak w tekście pierwszego tłumaczenia na język polski dokumentów Soboru Watykańskiego II (1967 r.). W tłumaczeniu z 2002 r. w „Skorowidzu rzeczowym” jest „znaki czasów”, zaś w najważniejszym fragmencie KDK nr 4 odnoszącym się do wspomnianego wyrażenia mamy (pewnie przez przeoczenie?) „,czas” w liczbie pojedynczej. Inne teksty mają już formę liczby mnogiej, np. DE 4; DP 9.
} 
obserwować i umiejętnie interpretować, bo są objawieniami i manifestacjami kryjących się za nimi, czy po nich następujących zmian w mentalności ludzi. W takim ujęciu nie traktuje się znaków czasu jako zdarzeń nadzwyczajnych, jak to ma miejsce $\mathrm{w}$ rozumieniu biblijnym, ani jako kryterium rozpoznawania prawdziwości misji Chrystusa, lecz jako wskazówki orientujące w jakim kierunku powinna pójść nauka Kościoła, by nie rozminęła się z rzeczywistością człowieka. Według M. Filipiaka znaki czasu w teologii nie są tym samym co w Biblii. W Biblii formuła znaki czasu odnosiła się do rzeczywistości historycznej, związanej z życiem i działalnością Jezusa Chrystusa i mówiła o spełnianych przez Niego nadzwyczajnych czynach, które miały służyć do rozpoznawania prawdziwości Jego nauki czy autoryzacji misji (Mt 16, 1-4). Język teologiczny rozszerzył zakres pojęcia znaki czasu oraz zmienił jego sens. Odnosi się ono nie do jednej epoki, lecz do czasów obecnych i przyszłych. Przez znaki czasu rozumie się nie jakieś czyny nadzwyczajne mające uwierzytelnić czyjeś posłannictwo, lecz charakterystyczne zjawiska i procesy historyczne, będące symptomami nowych potrzeb i aspiracji ludzkich. Nadzwyczajnym czynom Jezusa w Biblii - znakom czasu, w języku teologicznym odpowiadają zdarzenia i procesy historyczne czasów obecnych. Czyny Jezusa miały uwierzytelniać Jego misję; zdarzenia i procesy mają być wskazówkami orientującymi, w jakim kierunku powinna pójść nauka Kościoła, aby sprostać nowemu światu. M. Filipiak widzi w odniesieniu biblijnej formuły znaków czasu do innej sytuacji historycznej niż w Biblii i nadania jej innego znaczenia zabieg stosowany w teologii i liturgii Kościoła zwany akomodacją lub tzw. sensem przystosowanym ${ }^{27}$.

Stanowisko to przywołuje wątpliwości zgłaszane przez katolickich biblistów i protestanckich obserwatorów na Soborze Watykańskim II, którzy podkreślali, że wyrażenie semeia ton kairon odnosi się do epoki mesjańskiej i nie ma nic wspólnego z czasem w rozumieniu chronos. Biblia pod synonimem znaków czasu rozumiała rzeczy najświętsze, sferę sakralną, osobę Mesjasza i nadejście Królestwa Bożego. Współczesne wydarzenia, procesy historyczne czy społeczne są często wynikiem działania ślepych sił przyrody, efektami zamiarów ludzkich, a nie Bożych. Uważano, że papieże używali tego pojęcia w znaczeniu przedteologiczny, a nie biblijnym ${ }^{28}$.

Powyższe rozważania pozwalają stwierdzić, że w literaturze polskiej definicją znaków czasu, która stara się uwzględnić większość wspomnianych wyżej kwestii jest definicja Józefa Majki. Określa on znaki czasu jako szczególne wydarzenia $w$ historii ludzkości, $w$ życiu społecznym lub nawet $w$ życiu poszczególnych jednostek. Pozostaja one w ścistym zwiazku asocjacyjnym ze zbawcza inicjatywa Boga $w$ stosunku do człowieka, która rozwija się $w$ czasie, jak

${ }^{27}$ Por. M. F i 1 i p i a k: Fenomen „teologii znaków czasu”. „Euhemer”. R. 31: 1987 nr 1 s. 174-177; zob. Ż y n e 1, dz. cyt., s. 1580.

${ }^{28}$ P o t u r z y ń s ki, dz. cyt., s. 91. 
również z działaniem Ducha Świętego w historii ludzkiej, tak iż pozwalaja one na odczytanie tego, czego Bóg od nas w danym czasie, w określonych okolicznościach oczekuje ${ }^{29}$.

Na uwagę zasługuje również próba zdefiniowania znaków czasu dokonana przez Stanisława Bieleckiego, który określa je jako zjawiska, wydarzenia, procesy, w których przejawia się dziatanie Ducha Świętego, ingerującego w dzieje ludzkości przez pobudzanie i oświecanie ludzkich serc, które wymagaja konfrontacji $z$ nauka ewangeliczna $i$ zaangażowania chrześcijan; wobec tych zjawisk Kościót $i$ poszczególni chrześcijanie nie moga być obojętni, gdyż albo z nich samych, albo z Ewangelii z nimi skonfrontowanej wynika wezwanie do dziatania ${ }^{30}$.

Pojęcie znaki czasu przyczyniło się do ożywienia teologicznej refleksji nad Kościołem i światem, a także nad ich wzajemnymi odniesieniami. Z jednej strony w znakach czasu możemy odkryć syntezę epoki, ze wszystkimi jej trwałymi tendencjami, wydarzeniami, pragnieniami, a nieraz także dramatami. Z drugiej strony pojęcie znaki czasu, poprzez odniesienie do historii zbawienia, objawia ostateczny sens danej epoki, który zawarty jest w zamiarze i woli Boga. W ten sposób znaki czasu stają się wskaźnikami ewolucji dziejów zabawienia w ludzkiej historii i stanowią, obok Objawienia, źródło poznania i oceny ludzkiej rzeczywistości ${ }^{31}$. Znaki czasu są płaszczyzną prawdziwego dialogu pomiędzy Kościołem i światem. Dzięki nim świat „przemawia” do Kościoła i inspiruje go do wnikliwych badań teologicznych oraz wypracowywania nowych sposobów ewangelizacji i propozycji rozwiązywania rozmaitych problemów ludzkości i świata ${ }^{32}$.

Wydaje się, że w polskich publikacjach teologicznych po Soborze Watykańskim II problematyce znaków czasu poświęcono dużo miejsca. Tematyka współczesnych znaków czasu jest chętnie podejmowana, a to pociąga konieczność precyzowania, co rozumie się pod pojęciem znaki czasu. Można powiedzieć, że we wspomnianych publikacjach znajdujemy ciekawe próby definiowania i opisu znaków czasu w oparciu o nauczanie Kościoła współczesnego i dorobek polskiej i zagranicznej myśli teologicznej. Poszukiwaniom tym towarzyszy świadomość trudności napotykanych przy definiowaniu tak złożonego zjawiska, jakim są znaki czasu. Pomimo tych trudności należy mieć nadzieję, że Kościół w Polsce

\footnotetext{
${ }^{29}$ M a j k a: Metodologia nauk teologicznych, dz. cyt., s. 242.

${ }^{30}$ S. B i e l e c k i: Znaki czasu. W: Leksykon teologii pastoralnej. Red. R. K a m i ń s k i, W. Przy g o d a, M. Fi ałk ow s ki. Lublin 2006 s. 923.

${ }^{31}$ Por. S. P a w iń s k i: Święci jako ,znaki czasu” dla Kościoła w Polsce. Nauczanie Jana Pawta II w czasie jego pielgrzymek do Polski. Opole 2003 s. 28.

${ }^{32}$ Por. G o c k o, dz. cyt., s. 398.
} 
posłuszny poleceniom Soboru Watykańskiego II będzie kontynuował zadanie badania i interpretowania znaków czasu w świetle Ewangelii (KDK 4), aby ludzi naszych czasów doprowadzić do zbawienia. 